\title{
Cashless Economy: Epitomizing the Role of Various Institutions in Promoting Digital Literacy
}

\author{
Sushma Karnati ${ }^{1}$, Dr. Niyaj Sheikh ${ }^{2}$ \\ 1 Research Scholar, Department of Management, Gondwana University \\ ${ }^{2}$ Assistant Professor, Department of Management, Institute of Management Studies and Research, Kosara, Chandrapur
}

\begin{abstract}
It was a move that could have brought India's economy to a shuddering halt. Indeed, the seemingly endless queues outside banks, and the difficulty of spending cash at shops and stalls may have seemed like it did. But the decision to demonetize the 500 and 1,000 rupee notes was just one in a series of moves that will push India towards a digital economy. The demonetization was implemented with the aim of eliminating societal corruption and counterfeit currency. But the move was sudden, happening overnight. The two notes accounted for $86 \%$ of the bank notes in circulation in India, and retailers and consumers were forced to look immediately for options. Many turned to digital paying systems. The digital money strategy has been laid out by Prime Minister Modi's government from its early days in power, via a string of major decisions. The vision of Digital India aims to transform the country into a digitally empowered society and knowledge economy. Digital literacy assumes paramount importance at an individual level for truly and fully leveraging the potential of the Digital India programme. It provides citizens with the ability to fully exploit the digital technologies to empower themselves. It helps them seek better livelihood opportunities and become economically secure. Digital India campaign is a new concept which has a potential of transforming India into a knowledge economy powered by digital connectivity and the technological opportunities. Digitization of India will not only increase the efficiency of the government and public sector but also bring growth in the economy. Thus this paper focuses on role of Various Institutions in Promoting Digital Literacy in present scenario.
\end{abstract}

Keywords: NDLM, Digital India, CSC Training Programmes, MHRD, HRD Campaign

\section{INTRODUCTION:}

As India takes a step towards building a cashless economy, it's becoming clear that the biggest challenge to Narendra Modi's vision for a cashless country will come from Bharat. Digital Technologies, which include Cloud Computing and Mobile Applications, have emerged as catalysts for rapid economic growth and citizen empowerment across the globe. Digital technologies are being increasingly used by us in everyday lives, from retail stores to government offices. They help us connect with each other and also share information on issues and concerns faced by us. In some cases they also enable resolution of those issues in near real time. Though the cashless economy is a welcome initiative, the first requirement is digital literacy among the public followed by necessary software development and security. In a cashless economy, transactions will become transparent and things happening in the backend can be controlled. But it will not happen overnight as there are many challenges to overcome. The government is trying to encourage digitization as much as possible because an excessive cash economy has its own social and economic costs and consequences. The government has given lot of incentives to the people to shift to digital mode of payment and the response is quite positive in this regard. Long before demonetizing $500 \& 1000$ rupee notes, Indian government is trying to increase cashless transactions through Direct Benefit Transfer Scheme, Jan Dhan accounts etc. From the moment higher denomination notes are demonetized, cashless transactions have increased at a rapid rate. The challenge to go digital a major obstacle for the quick adoption of alternate mode of payments is mobile internet penetration, which is crucial because point-of-sale terminal works over mobile internet connections, while banks have been charging money on card-based transactions, which is seen as a hurdle. The low literacy rates in rural India, along with the lack of infrastructure like internet access and Power make things extremely difficult for people to adopt e-transaction route. Many state governments are working hard to spread the awareness of digital transactions. Indian Government rolled out incentives for going digital in financial transactions. It introduced daily and weekly lucky draws to encourage digital transactions. Digital Literacy is the ability of individuals and communities to understand and use digital technologies for meaningful actions within life situations.

\author{
Objectives: \\ - To know the need for digital literacy \\ - $\quad$ To understand the various measures and schemes adopted by various institutions to promote digital literacy
}

\section{Need for digital literacy}

Digital transactions have been on a sharp upswing after the government's demonetization drive to move towards a less-cash economy. Millions of shopkeepers, roadside vendors, auto drivers and eateries across the country are boarding the digital bandwagon. The average literacy rate surely plays a role in the success of cashless transaction plans of the state government. Many villages don't have proper banking services and more than 20 per cent of the eligible people don't have bank accounts. Moreover, it is not feasible to force illiterate people to use debit and credit cards in the name of cashless transactions as the banking system in India is still unsecured and many fraudulent practices like online money thefts continue to occur. Many literate people also don't know how to operate cards in a proper manner. Literate people may know the basics of cashless transactions such as net-banking and use of debit and credit cards. But if a person does not know the basics, they can be easily cheated by 
fraudsters. Every person including illiterate people hailing from villages must have knowledge about the banking system. Awareness and improvement in the India's literacy rate should be achieved before realizing the dream of Digital India. The present crisis has forced the people to go for digitalized transaction methods including net-banking and online payment. Ensuring financial and digital inclusion alone is not sufficient to transition to a cashless economy. The citizens should also be made aware of the financial and digital instruments available and how to transact using them.

\section{Role of Various Institutions in Promoting Digital Literacy}

To promote digital literacy various institutions has taken initiatives. These include educational institutions, government, banks etc., they provide various missions and schemes to bring digital literacy among the people towards the vision of cashless economy. The following are the few measures adopted by various intuitions in present scenario.

\section{National Digital Literacy Mission - NDLM}

Making one person in every family digitally literate is one of the integral components of the Prime Minister's vision of "Digital India". The Digital Saksharta Abhiyan (DISHA) or National Digital Literacy Mission (NDLM) Scheme has been formulated to impart IT training to 52.5 lakh persons, including Anganwadi and ASHA workers and authorised ration dealers in all the States/UTs across the country so that the non-IT literate citizens are trained to become IT literate so as to enable them to actively and effectively participate in the democratic and developmental process and also enhance their livelihood. Altogether 52.5 lakh persons, including Anganwadi and ASHA workers and authorised ration dealers will be trained under the programme in two phases. In the first phase, 10 lakh beneficiaries will be trained under the scheme. Nine lakh beneficiaries will be eligible for training fee support from the government. The rest 100,000 beneficiaries will be trained by the industry and civil society partners.

\section{Role of Training Centres \\ The training centres are responsible for the following:}

- $\quad$ Conduct of household survey and digitization of data

- Selecting the beneficiaries eligible under the project and enrolling them for the course

- Imparting the appropriate training course to beneficiaries eligible under the project, including providing course materials

- Registering the beneficiaries, marking the attendance, and conducting the continuous assessment.

\section{Digital India}

Digital India is an ambitious programme of Government of India projected at Rs 1,13,000 crores. This will be for preparing the India for the knowledge based transformation and delivering good governance to citizens by synchronized and co-ordinated engagement with both Central and state government. This programme has been envisaged by Department of Electronics and Information Technology (DeitY) and will impact ministry of communications \& IT, ministry of rural development, ministry of human resource development, ministry of health and others. This programme will also benefit all states and union territories. The existing/ ongoing e-Governance initiatives would be revamped to align them with the principles of Digital India. The vision of Digital India is to transform the country into a digitally empowered society and knowledge economy. It would ensure that government services are available to citizens electronically. It would also bring in public accountability through mandated delivery of government services electonically. Under the concept of digital army, the master trainers would be identified and trained through CSCs at the state, district and development block level. Mobile phone owners, government employees and selfhelp groups would also be imparted training eventually. To reach out to masses for operating e-transactions, around 7000 Common Service Centres (CSC) - eservice providers by state's Information Department CHIPS had already been pitched in for the cause. Efforts are being made to create awareness and impart training to the rural masses for online transactions through CSC.

\section{Government Fast-Tracks CSC Training Programmes to Spread Digital Literacy}

The government's digital financial literacy training plan for 2.5 million people, CSC e-Governance Services India Ltd, under the ministry of electronics and information technology (IT), has started the process of creating new content in its existing courses to fast-track the project. This comes at a time when the use of old 500 and 1,000 banknotes have been banned by the National Democratic Alliance government leading to shortage of cash in circulation. Common Service Centers (CSCs) provide modules on financial literacy in partnership with the National Bank for Agriculture and Rural Development educating people about current and savings account, and other basic banking services. Another programme on investor education in partnership with the department of corporate affairs deals with various aspects of investing money.

\section{Educational Institutions in Digital Literacy:}

To make the faculty, students and staff aware about the use of online transactions and promote a cashless economy, various awareness programme and workshops have been arranged by the university to encourage them to use online payment modes and e-wallets for their daily expenses.

- JNU has taken initiatives to promote the Digital Financial Literacy campaign recently launched by MHRD, Government of India. Communication and Information Services (CIS) will provide Digital Financial Literacy Training and facilitate access to such instruments, implement online payment systems for JNU Community. It is requested all JNU community to encourage their colleagues to use cashless transactions and also instructed to start all procurement process either official or non-official through emedium. Special sessions will also be organized by the CIS, bank representatives to make JNU personnel aware about the online system in the campus. The move will also help the JNU community to aware with the new age banking, online payment systems. 
The efforts are also being made to improve the online infrastructure to ensure that each and every personnel of JNU can be benefited and motivate their family members as well as relatives. This move will definitely encourage the overall cashless transactions of the campus as well as procurement system in the university and encourage all personnel to go cashless as it is convenient, secure and reduce time and cost. As part of a significant initiative by the Government of India for Digital India and move the country in the direction towards making the economy less cashless, and the MHRD's initiative for promoting an awareness programme across the universities and colleges in the country.

The role of the students and their active participation is critical to spread awareness among people within the JNU campus as well as nearby areas/villages/shops and market places etc., including select households and family members.

\section{- $\quad$ HRD launches campaign to promote digital transactions:}

HRD Minister Prakash Javadekar launched a campaign to use the network of Centrally-run educational institutions for propagating the benefits of digital mode of payment in wake of the government's demonetization move. He Addressed IITs, NITs, IIITs, IIMs and Central universities through a video conference, Javadekar urged the academic community to become part of India's growth story than being mere witnesses to the "revolutionary change" brought about by the demonetization decision.

\section{Banks in Digital Literacy}

Any effort by a bank or institution to undertake financial literacy is always welcome as it helps people become less cash dependent as they start to embrace digital methods of payment. However, a majority of Indian villages have low or no Internet connectivity, which is crucial for digital transactions.

Against the backdrop of the demonetization drive, ICICI Bank, the country's largest private sector bank, will make 100 villages cashless and adopt digital modes of payment within 100 days. The bank will be training 10,000 villagers in using digital methods of transaction and will also offer them vocational training.

The digital economy in the aftermath of demonetization of Rs 500 and Rs 1,000 currency, bankers are trying to sell cashless transactions among people, especially from the rural areas. At Suttur, where the Jathra mahotsava is on, JSS Mahavidyapeetha has set up booths to deconstruct the idea and help the villagers get a hands-on experience. Hundreds are thronging the booth opened exclusively to create awareness about cashless transactions. The organizers have set up seven such centres, especially where there are big crowds. At each kiosk, 15-20 trained people, especially students, are engaged in raising awareness among the people. A majority of the people, especially from rural areas who were not very aware about the system.

\section{Conclusion:-}

Though cashless transactions have increased these days, right now India cannot completely become a cashless economy considering its high proportion of digital illiteracy and cash transactions. But Indian Government is working towards increasing the share of cashless transactions, which is a good thing for the economy. The process requires every ones active participation so that all levels of transactions in India becomes digital as Digital Literacy Mission is a key component of Digital India initiative in present cashless economy.

\section{REFERENCES:}

[1] Sherin T. Abraham1 and Raji Joseph, "Digital Financial Inclusion Initiatives in India", DISCOURSE Xavierian Research Journal 4(1) 2016.

[2] Sherin T. Abraham1 and Raji Joseph, "Digital Financial Inclusion Initiatives in India", DISCOURSE Xavierian Research Journal 4(1) 2016.

[3] Marcus Wohlsen, "Digital Literacy Is the Key to the Future, But We Still Don't Know What It Means", Business, september 2014.

[4] Aharon Aviram, “Towars A Theory Of Digital Literacy The Next Steps”,EURODL, September, 2016.

[5] Dr Turka Suresh Kumar, Singh Gurcharan, "Issues and Challenges of Digital India Programme in the Current Scenario", Academic Discourse,2016.

[6] Sumita Santra, Knowledge Society and Digital India Program as a Venture to Demolish the Wall of Digital Divide, IJIMS, Vol 2, 2015.

[7] Digital India [Online] Available from https://en.wikipedia.org/wiki/Digital_India

[8] Ms. deepika sahdev, dr. nitya sharma, epitomising vitality of digital india, international journal of business management and scientific research, vol : 18, june 2016.

[9] Sharma, S.K, "Digital India: A Vision Towards Digitally Empowered Knowledge Economy" Indian Journal of Applied Research Volume : 5 , Issue : 10 , October 2015.

[10] Colin Lankshear And Michele Knobel, “Digital Literacies_Concepts, Policies and Practices”,2008. 